\title{
Cave bats in Jamaica
}

Donald A. McFarlane

Jamaica has 22 native mammal species. One of these is an endangered rodent, the Jamaican hutia Geocapromys browni; the rest are all bats. Fifteen of these bats depend entirely or significantly on caves as roost sites, including two endemic species and seven endemic subspecies. These cave-dwelling bats often form large colonies whose guano deposits are of significant economic value as fertilizer, but which are vulnerable to disturbance and roost destruction. The author, who has visited and worked in many of Jamaica's bat caves over the past eight years, is currently researching the evolution and development of the Antillean bat faunas.

Of Jamaica's 950 documented caves (Fincham, 1977), approximately 17 per cent are known to host bat colonies of sizes varying from a few dozen to tens of thousands of individuals. The cave-dwelling bats of Jamaica are not evenly distributed amongst these caves, and a mere handful of large caves account for all the known colonies of some of the rarest species. These caves are typically occupied by several species of bat whose combined numbers produce large quantities of guano, which may be harvested commercially as a high-grade fertilizer. Indeed, one of the first systematic surveys of Jamaican caves was undertaken by the Geological Survey Department of Jamaica specifically to locate and assess economic reserves of bat guano (McGrath, 1950-1965). Ironically, this commercial interest both threatens and, perhaps, protects the animals. Clearly, it is in the interests of those landowners who harvest guano to ensure the continued well-being of the bat colonies in their caves, but at the same time careless harvesting Cave bats in Jamaica may cause serious disturbance to the colonies. Wallingford Cave, in St Elizabeth Parish, is a large but short blind tunnel close to a road that was for a time mined for its guano deposits (Peck, 1975). By August 1977 the bat colony had disappeared, and it seems possible that excessive disturbance may have been responsible.

An examination of the literature suggests that 15 of Jamaica's bats are significantly or entirely dependent on caves as day roosts (Table 1). Six of these species are of special concern and are discussed below. Taxonomy and vernacular names follow Hall (1982).

\section{The Jamaican flower bat Phyllonycteris aphylla}

This bat is endemic to Jamaica and is known from only three caves: St Clair Cave, Riverhead Cave, and Mt Plenty Cave (Goodwin, 1970). Its subfossil remains have been found in 'Dairy Cave' (Runaway Bay Caves) and Wallingford Cave (Koopman and Williams, 1951). Its total population is unknown, but the only sizeable colony is in St Clair Cave and numbers perhaps a few hundred individuals. The fact that $P$. aphylla is no longer found at Runaway Bay and Wallingford Caves suggests that there may have been some abandonment of former roosts. Alternatively, if the subfossils from these caves are owl pellet remains rather than roost deposits, then the status of this species in these areas is completely unknown.

As far as is known, $P$. aphylla is a gregarious, obligate cave dweller forming colonies of up to a few hundred individuals in large cave passages shared with other species. Such caves are few in 
Table 1. Jamaica's cave bats and their distribution in the island's important bat caves

\begin{tabular}{|c|c|c|c|c|c|c|}
\hline \multirow[b]{2}{*}{ Jamaican cave bats } & \multirow[b]{2}{*}{ Obligate cave dweller? } & \multicolumn{5}{|c|}{ Important caves } \\
\hline & & Endemic? & St Clair & Oxford & Windsor & Mt Plenty \\
\hline Pteronotus quadridens fuliginosus & Yes & No & + & + & - & - \\
\hline Pteronotus macleayii griseus & Yes & Subspecies & + & + & + & + \\
\hline Pteronotus parnelli parnelli & Yes & No & + & + & + & + \\
\hline Aello cuvieri & Yes & No & + & + & - & + \\
\hline Macrotus waterhousii jamaicensis & No? & Subspecies & - & - & + & - \\
\hline Glossophaga sorcina antillarum & Yes & No & - & - & - & - \\
\hline Monophyllus redmani redmani & Yes & Yes & + & + & + & + \\
\hline Artibeus jamaicensis jamaicensis & No & No & - & - & - & + \\
\hline Erophylla sezekomi syops & Yes & Yes & + & - & - & + \\
\hline Phyllonycteris aphylla & Yes & Yes & + & - & - & + \\
\hline Natalus stramineus major & Yes & Yes & + & - & - & - \\
\hline Natalus microps & Yes & Yes & + & - & + & - \\
\hline Eptesicus lynni & Yes? & Yes? & - & - & - & - \\
\hline Molossus molossus milleri & No & No & - & - & - & - \\
\hline Tadarida macrotis & No? & No & - & - & - & - \\
\hline
\end{tabular}

number and are typically associated with abandoned river resurgences. Little else is known of the ecology of this bat. Novick and Leen (1969) report that $P$. aphylla is unable to bite into firm fruit, but feeds on juice and pulp from overripe and damaged fruit on the ground. The papillose, protusible tongue implies an emphasis on pollen and nectar feeding, so that it is likely that the species would exhibit a dietary shift from pollen and nectivory in the dry season to frugivory in the wet season. Goodwin (1970) reports a female with embryo taken in late January, but nothing else is known of the species's reproductive habits.

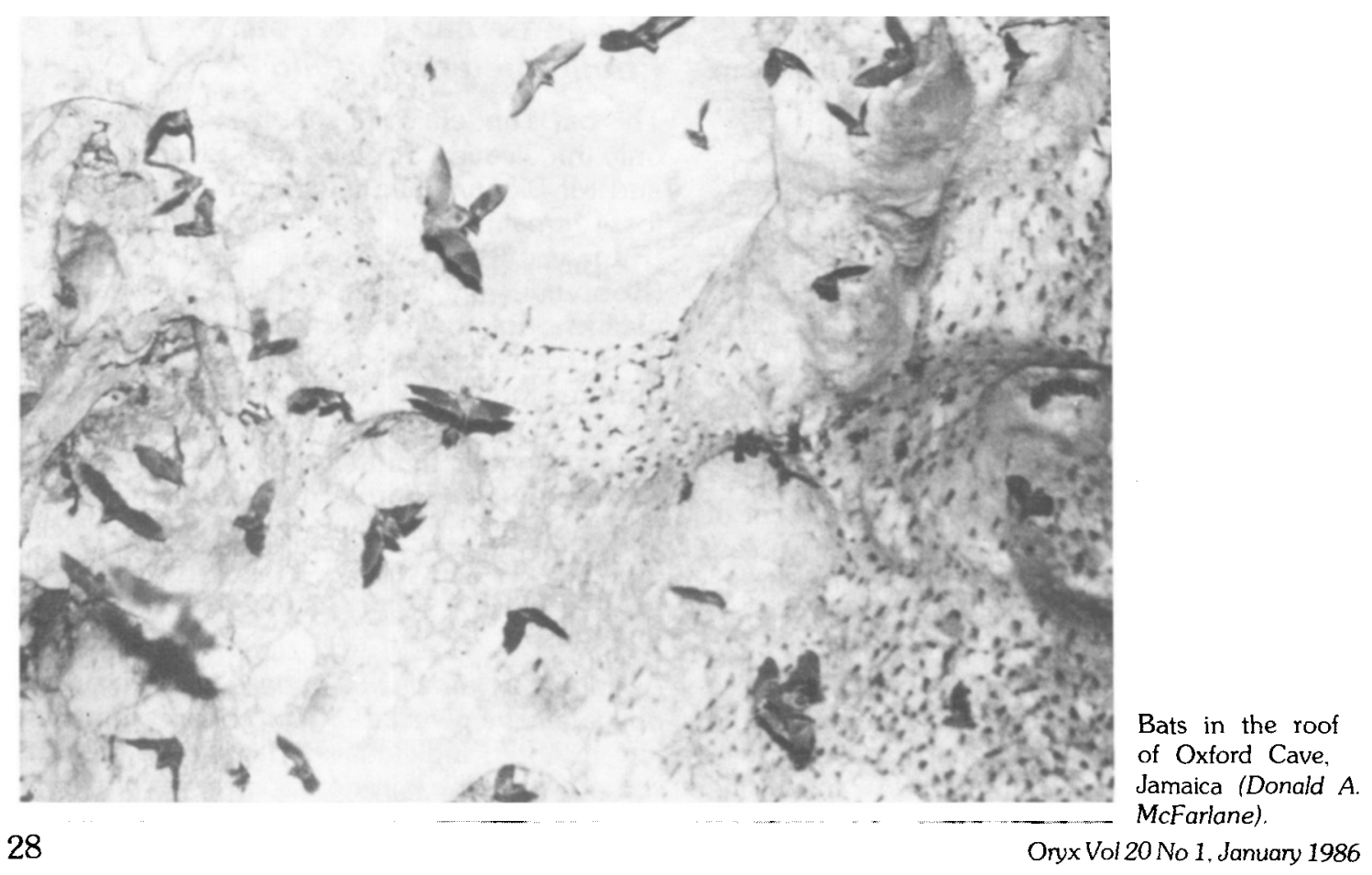




\section{The buffy flower bat Erophylla sezekorni syops}

This is a rare endemic subspecies of a genus restricted to the Greater Antilles and Bahamas, and is known from just three caves: Mt Plenty Cave, Sewell Cave and St Clair Cave. Only the St Clair Cave population is known to be of any size, numbering at most several hundred individuals (Goodwin, 1970). From what little is known, the ecology of the species is similar to that of $P$. aphylla. The species is apparently much more common on Cuba (Nowak and Paradiso, 1983), which suggests that the Jamaican subspecies has either escaped attention or perhaps is in decline.

\section{The Cuban funnel-eared bat Natalus micropus micropus}

This endemic subspecies is known from three localities: St Clair Cave (Goodwin, 1970), Monarva Cave (personal observation, 1983) and Windsor Cave (Kerridge and Baker, 1978). Each of these caves is warm, very humid, and supports a large population of several bat species. In St Clair Cave the population has been estimated at several hundred, and the species is probably present in Monarva Cave in similar numbers. The
Windsor Cave population is of unknown size, since only a single individual has been trapped there. These bats are strictly insectivorous, and apparently rather slow fliers.

\section{The Mexican funnel-eared bat Natalus stramineus jamaicensis}

This endemic subspecies is apparently even rarer and less well known than $N$. micropus. Living animals are known only from St Clair Cave, where the population is crudely estimated to be only about one-third of that of $N$. micropus (Goodwin, 1970). A single subfossil specimen has been recovered from Wallingford Cave (Koopman and Williams, 1951). The ecology of the species is presumed to be similar to that of $N$. micropus and the mainland forms of $N$. stramineus, which are themselves poorly studied.

\section{Lynn's brown bat Eptesicus lynni}

This endemic species is known only from the original discovery in an unnamed cave near Montego Bay (Shamel, 1945), three misidentified specimens caught in Sherwood Forest

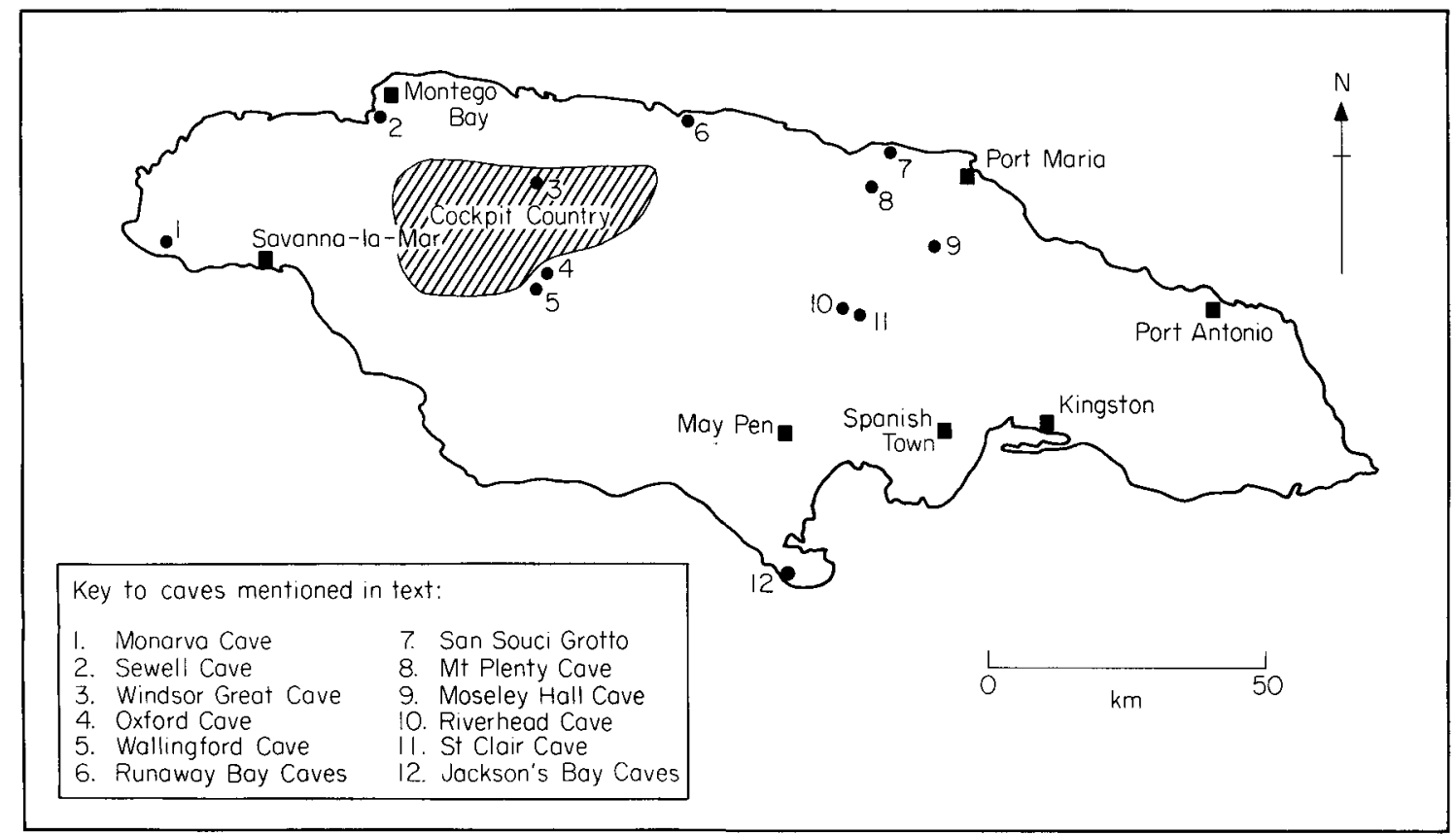

Figure 1. Important bat caves of Jamaica. 
(Sanborn, 1941), and a more recent collection of three specimens from Runaway Bay Caves (quoted as 'Green Grotto') (Arnold et al., 1980). Nothing is known of its ecology, but its morphological similarity to other members of its genus suggests that it is an aerial insectivore. The proposed South American affinities of this species make it of special interest in the understanding of Caribbean zoogeography.

\section{Leach's long-tongued bat Monophyllus redmani redmani}

An endemic subspecies of a genus confined to the Antilles and Bahamas, M. redmani has been recorded from six Jamaican caves: Oxford Cave, Moseley Hall Cave, St Clair Cave, Windsor (Great) Cave, Mt Plenty Cave and San Souci Grotto (Goodwin, 1970; personal observation, 1983). The anatomy of the tongue and muzzle suggests a largely nectivorous habit similar to that of the better known Glossophaga sorcina, which takes soft fruit, nectar and insects. Pregnant Monophyllus caught in December, January and February on Hispaniola, Jamaica and Puerto Rico constitute the available evidence on reproduction.

Although Monophyllus redmani forms large colonies and is a common bat in a few large caves, the subspecies must be considered vulnerable until it can be shown to be more widely distributed in the smaller caves of the island. The record from San Souci Grotto provides hope that this may indeed be the case.

Sound ecological and distributional data on these, and most other Jamaican bats, is woefully lacking. Non-cave dwellers such as the endemic genus Ariteus are even less well known. The fact that a number of Jamaica's endemic species and subspecies are known from only a few unusually large caves is a warning of their vulnerability. In view of the many years of effort that have been invested in cave exploration on the island, it is unlikely that many more big bat caves remain to be discovered. It is therefore of great importance that attention be given to studying the very many smaller bat caves to determine which species use them.

Jamaica's cave bats do not currently seem to be 30 under direct threat other than through disturbance by excessive numbers of curious visitors or guano diggers. Legislation to protect some of the more important caves-these would include Oxford, Mt Plenty, Windsor and St Clair Caveswould serve to focus official attention and monitoring on these sites, but in realistic terms such legislation would be unenforcable as a practical measure. Since most of these caves are located on or near smallholdings or other agricultural concerns, probably the best protection would be afforded through education at the agricultural development centres, which offer advice and training to farmers throughout the island. Furthermore, in the event that Jamaica does establish national parks in any of the remaining wilderness areas (see Mittermeier, 1972) it is to be hoped that due attention will be paid to the unique but poorly understood bat fauna.

\section{References}

Arnold, M.L., Baker, R.J. and Genoways, H.H. 1980. Evolutionary origin of Eptesicus lynni. Joumal of Mammalogy, 61 (2), 319-322.

Fincham, A.G. 1977. Jamaica Underground: A Register of the Caves of Jamaica. Geological Society of Jamaica. Kingston.

Goodwin, R.E. 1970. The ecology of Jamaican bats. Journal of Mammalogy, 51 (3), 571-579.

Hall, E.R. 1982. The Mammals of North America. John Wiley and Sons, New York.

Kerridge, D.C. and Baker, R.J. 1978. Natalus micropus. Mammalian Species, 114, 1 -3.

Koopman, K.F. and Williams, E.E. 1951. Fossil chiroptera collected by H. E. Anthony in Jamaica, 1919-1920. American Museum Novitates, 1519, 1-29.

McGrath, B.R.G. 1950-1965. Surveys and field notes in the records of the Department of Mines and Geology, Kingston, Jamaica. (Unpublished).

Mittermeier, R.A. 1972. Jamaica's endangered species. Oryx, XI, 258-262.

Novick, A. and Leen, N. 1969. The World of Bats. Holt, Reinhart and Winston, New York.

Nowak, R.M. and Paradiso, J.L. 1983. Mammals of the World, 4th edn, Vol. 1. Johns Hopkins University Press, Baltimore.

Peck, S.B. 1975. The invertebrate fauna of tropical American caves. 3. Jamaica - an introduction. International Joumal of Speleology, 7, 303-326.

Sanborn, C.C. 1941. Descriptions and records of Neotropical bats. Field Museum of Natural History, (Zoology), 27,371387.

Shamel, H.H. 1945. A new Eptesicus from Jamaica. Proceedings, Biological Society of Washington, 58, 107-110.

Donald A. McFarlane, Section of Birds and Mammals, Natural History Museum of Los Angeles County, 900 Exposition Boulevard, Los Angeles, CA 90007, USA.

Oryx Vol 20 No 1, January 1986 